\title{
The role of hypercapnia in acute respiratory failure
}

\author{
Luis Morales-Quinteros ${ }^{1 *}$ (D), Marta Camprubí-Rimblas ${ }^{2,4}$, Josep Bringuée ${ }^{2,9}$, Lieuwe D. Bos ${ }^{5,6,7}$, \\ Marcus J. Schultz ${ }^{5,7,8}$ and Antonio Artigas $1,2,3,4,9$
}

From The 3rd International Symposium on Acute Pulmonary Injury Translational Research, under the auspices of the: 'INSPIRES ${ }^{\oplus 1}$

Amsterdam, the Netherlands. 4-5 December 2018

\footnotetext{
* Correspondence: luchomq2077@ gmail.com

${ }^{1}$ Intensive Care Unit, Hospital Universitario Sagrado Corazón, Carrer de Viladomat, 288, 08029 Barcelona, Spain

Full list of author information is available at the end of the article
}

\begin{abstract}
The biological effects and physiological consequences of hypercapnia are increasingly understood. The literature on hypercapnia is confusing, and at times contradictory. On the one hand, it may have protective effects through attenuation of pulmonary inflammation and oxidative stress. On the other hand, it may also have deleterious effects through inhibition of alveolar wound repair, reabsorption of alveolar fluid, and alveolar cell proliferation. Besides, hypercapnia has meaningful effects on lung physiology such as airway resistance, lung oxygenation, diaphragm function, and pulmonary vascular tree.

In acute respiratory distress syndrome, lung-protective ventilation strategies using low tidal volume and low airway pressure are strongly advocated as these have strong potential to improve outcome. These strategies may come at a price of hypercapnia and hypercapnic acidosis. One approach is to accept it (permissive hypercapnia); another approach is to treat it through extracorporeal means. At present, it remains uncertain what the best approach is.
\end{abstract}

Keywords: Acute respiratory failure, Acute respiratory distress syndrome, Carbon dioxide, Permissive hypercapnia, Hypercapnia, Hypercapnic acidosis

\section{Background}

Patients with acute respiratory failure almost always develop gas exchange derangements that may result in hypercapnia [1]. Lung-protective ventilation strategies are strongly recommended to prevent additional lung injury [2, 3], but these strategies have a strong potential to increase plasma carbon dioxide levels further. One approach is to accept this, i.e., "permissive hypercapnia," with the option to correct respiratory acidosis by slow bicarbonate infusion for blood buffering. Extracorporeal decapneization by utilizing "extracorporeal $\mathrm{CO}_{2}$ removal" $\left(\mathrm{ECCO}_{2} \mathrm{R}\right)$ is an appealing alternative for permissive hypercapnia but comes with the typical risks of extracorporeal circulation.

Hypercapnia has been suggested to have beneficial effects, including a reduction in pulmonary inflammation and alveolar oxidative stress [4-7]. Hypercapnia, however, may also have deleterious effects, such as impairments in tissue repair and decreased

(c) The Author(s). 2019 Open Access This article is distributed under the terms of the Creative Commons Attribution 4.0 International License (http://creativecommons.org/licenses/by/4.0/), which permits unrestricted use, distribution, and reproduction in any medium, provided you give appropriate credit to the original author(s) and the source, provide a link to the Creative Commons license, and indicate if changes were made. 
alveolar fluid clearance [8-11]. Seen these seemingly opposite effects, it becomes increasingly important to determine the net consequence of hypercapnia. Indeed, the number one question in patients with acute respiratory distress syndrome (ARDS), who either have hypercapnia or develop hypercapnia as a consequence of lung-protective ventilator settings, is whether hypercapnia should be accepted, or prevented and corrected.

This narrative review provides an overview of the various biological and physiological effects of hypercapnia and discusses current strategies affecting the plasma carbon dioxide levels in ARDS patients.

\section{Biological effects of hypercapnia_preclinical studies}

Several preclinical studies have shown hypercapnia displays profound impact on alveolar cells and humoral factors that all could play a role in lung injury. Some of these effects can be seen as potentially beneficial, while others, in theory, could be harmful.

\section{Effects of hypercapnia on alveolar cells (Table 1)}

Hypercapnia has been found to decrease microvascular permeability, lung edema formation, and bronchoalveolar lavage protein content in the rabbit lungs subjected to ex vivo ventilation with high pressures [4]. Hypercapnia also reduced histologically confirmed lung injury in ventilated mice [5]. The plausible mechanisms are related to the action of carbon dioxide upon the nuclear factor kappa pathway, which prevents p65 translocation and reducing inflammation $[12,13]$.

It also attenuated apoptosis in rabbits subjected to ischemia and reperfusion injury [6], and buffering hypercapnic acidosis worsened lung injury in this model [14]. One of the proposed mechanisms is the inhibitory action of $\mathrm{CO}_{2}$ on the ADAM-17 (a sheddase), thus preventing the activation of the p44/p42 MAPK pathway and, by this way, reducing apoptosis [15]. Finally, hypercapnia resulted in less cell injury and neutrophil adherence to endothelial monolayers in stimulated pulmonary endothelial cells [16].

Table 1 Alveolar cellular effects of hypercapnia: summary of in vivo and ex vivo experiments on the effects of hypercapnia

\begin{tabular}{|c|c|c|c|}
\hline Study & Experimental model & Applied $\mathrm{CO}_{2}$ & Cellular effects \\
\hline $\begin{array}{l}\text { Broccard } \\
\text { et al. [4] }\end{array}$ & VILI ex vivo (rabbit) & $\begin{array}{l}\mathrm{PaCO}_{2} \text { target } \\
70-100 \\
\mathrm{mmHg}\end{array}$ & $\begin{array}{l}\text { HCA reduced microvascular permeability, I } \\
\text { ung edema formation, and BAL protein content }\end{array}$ \\
\hline $\begin{array}{l}\text { Yang } \\
\text { et al. [20] }\end{array}$ & $\begin{array}{l}\text { VILI in vivo (rat) and in vitro } \\
\text { alveolar epithelial cells }\end{array}$ & $\begin{array}{l}\mathrm{PaCO}_{2} \text { target } \\
80-100 \\
\mathrm{mmHg}\end{array}$ & $\begin{array}{l}\text { HCA attenuated microvascular leak, oxidative } \\
\text { stress, and inflammation }\end{array}$ \\
\hline $\begin{array}{l}\text { Doerr } \\
\text { et al. [65] }\end{array}$ & $\begin{array}{l}\text { VILI/plasma wound resealing. } \\
\text { Ex vivo (rat) and in vitro } \\
\text { alveolar epithelial cell }\end{array}$ & $12 \%$ & $\begin{array}{l}\text { Hypercapnia reduced plasma membrane } \\
\text { resealing in vivo and in vitro }\end{array}$ \\
\hline $\begin{array}{l}\text { OToole } \\
\text { et al. [8] }\end{array}$ & In vitro three cell respiratory lines & $10,15 \%$ & $\begin{array}{l}\text { Hypercapnia reduced rate of wound closure } \\
\text { (cell migration) via NF-KB pathway inhibition }\end{array}$ \\
\hline $\begin{array}{l}\text { O'Croinin } \\
\text { et al. [17] }\end{array}$ & E. coli pneumonia (48 h). In vivo (rat) & $8 \%$ & $\begin{array}{l}\text { Hypercapnia worsened lung injury induced by } \\
\text { prolonged untreated E. coli pneumonia }\end{array}$ \\
\hline $\begin{array}{l}\text { Wang } \\
\text { et al. [21] }\end{array}$ & $\begin{array}{l}\text { Endotoxin stimulation. In vitro } \\
\text { human and mouse macrophages }\end{array}$ & $\begin{array}{l}5,9,12.5 \\
20 \%\end{array}$ & $\begin{array}{l}\text { Hypercapnia inhibited macrophage } \\
\text { phagocytosis }\end{array}$ \\
\hline
\end{tabular}

HCA hypercapnic acidosis, VILI ventilator-induced lung injury, BAL bronchoalveolar lavage, NF-KB nuclear factor kappa B 
Contrasting, in rats exposed to hypercapnia for $48 \mathrm{~h}$, a challenge with Escherichia coli caused neutrophils to have impaired phagocytic activity, with higher bacterial colony counts in the lungs of these animals, possibly because of impairment in neutrophil function under sustained hypercapnic acidotic environment [17]. Hypercapnia worsened injury and induce apoptosis in alveolar type 2 epithelial cells via a nitric oxide-dependent pathway in an in vitro model with fetal rat alveolar cells pre-incubated with lipopolysaccharide (LPS) and cytokines [18]. Also, hypercapnia dose-dependently impaired alveolar cell proliferation and delayed wound repair in an in vitro scratch wound model of three different types of human lung cells [8]. These effects persisted with buffering of the hypercapnic acidosis. In line with this observation, in ex vivo and in vitro rat models of ventilator-induced lung injury (VILI), hypercapnic acidosis impaired membrane wound resealing. Carbon dioxide rather than $\mathrm{pH}$ reduced the rate of wound closure (cell migration) in a dose-dependent manner via NF-KB pathway inhibition. Furthermore, hypercapnia caused mitochondrial dysfunction and impaired cell proliferation in an in vitro model of cultured human alveolar epithelial cells by induction of miR-183, a microRNA, which in turn downregulated isocitrate dehydrogenase 2, a key enzyme of the tricarboxylic acid cycle that catalyzes the conversion of isocitrate to $\alpha$-ketoglutarate, leading to mitochondrial dysfunction and impaired proliferation of alveolar epithelial cells [19].

\section{Effects of hypercapnia on humoral processes (Table 2)}

Hypercapnia has been found to attenuate cytokine production and oxygen free radical formation in mice subjected to alveolar stretch [5, 15]. Furthermore, hypercapnia markedly reduced apoptosis, oxidative stress, and inflammation in alveolar epithelial cells from high-pressure ventilation-stimulated rat lungs [20]. Hypercapnic acidosis (HCA) exerts anti-inflammatory effects in rabbits with endotoxin-induced lung injury [16].

On the contrary, hypercapnia has been found to selectively inhibit the expressions of proinflammatory cytokines in human and mouse macrophage cell lines [21]. In in vitro human cells' experiments, hypercapnia inhibited activation of the NF- $\mathrm{B}$ pathway [13, 22], independent of $\mathrm{pH}$.

\section{Effects of hypercapnia on alveolar fluid clearance}

Hypercapnic acidosis reduced alveolar edema formation by inhibiting an increase in pulmonary capillary included by free radicals [7], ischemia-reperfusion [14], and high-stretch ventilation in in vitro and in vivo models [23].

However, hypercapnia has also been found to decrease alveolar fluid clearance by decreasing $\mathrm{Na}^{+}, \mathrm{K}^{+}$-ATPase activity in the alveoli basal membrane in in vivo studies in large and small animal models $[9,24]$, in ex vivo studies using a rodent lung model [10], and in human alveolar epithelial cells [11].

\section{Physiologic effects of hypercapnia-animal and human studies}

Several studies have shown various effects of hypercapnia on the respiratory system. 
Table 2 Humoral effects of hypercapnia: summary of in vivo and ex vivo experiments on the effects of hypercapnia

\begin{tabular}{|c|c|c|c|}
\hline Study & Experimental model & $\begin{array}{l}\text { Applied } \\
\mathrm{CO}_{2}\end{array}$ & Humoral effects \\
\hline Shibata et al. [7] & Free-radical ex vivo (rabbit) & $25 \%$ & $\begin{array}{l}\text { HCA attenuated free-radical injury via } \\
\text { inhibition of endogenous xanthine oxidase }\end{array}$ \\
\hline Laffey et al. [6] & Pulmonary IR ex vivo (rabbit) & $12 \%$ & $\begin{array}{l}\text { HCA reduced TNF-a, 8-isoprostane, } \\
\text { nitrotyrosine generation in the lung } \\
\text { tissue and reduced apoptosis }\end{array}$ \\
\hline Yang et al. [20] & $\begin{array}{l}\text { VILI in vivo (rat) and in vitro } \\
\text { alveolar epithelial cells }\end{array}$ & $\begin{array}{l}\mathrm{PaCO}_{2} \\
\text { target } \\
80-100 \\
\mathrm{mmHg}\end{array}$ & $\begin{array}{l}\text { HCA reduced caspase-3 activation } \\
\text { (apoptosis), MPO, MDA, via ASK-1-JNK/p38 } \\
\text { pathway inhibition }\end{array}$ \\
\hline Otulakowski et al. [15] & $\begin{array}{l}\text { VILI ex vivo (mouse) and } \\
\text { in vitro alveolar epithelial cells }\end{array}$ & $12 \%$ & $\begin{array}{l}\text { Hypercapnia prevented activation of EGFR } \\
\text { and p44/42 MAPK pathway in vitro. TNFR } \\
\text { shedding (on ADAM-17 ligand induced } \\
\text { by stretch injury) was reduced in vivo }\end{array}$ \\
\hline Takeshita et al. [16] & $\begin{array}{l}\text { Endotoxin in vitro pulmonary } \\
\text { endothelial cells }\end{array}$ & $10 \%$ & $\begin{array}{l}\text { Hypercapnia reduced cell injury and } \\
\text { prevented IkB degradation. } \\
\text { NF-kB-dependent cytokine production } \\
\text { was reduced }\end{array}$ \\
\hline O'Toole et al. [8] & $\begin{array}{l}\text { In vitro three cell } \\
\text { respiratory lines }\end{array}$ & $10,15 \%$ & $\begin{array}{l}\text { Hypercapnia inhibited p65 translocation } \\
\text { and IKB degradation }\end{array}$ \\
\hline Cummins et al. [13] & $\begin{array}{l}\text { Endotoxin stimulated. In } \\
\text { vitro six different cell lines }\end{array}$ & $5,10 \%$ & $\begin{array}{l}\mathrm{CO}_{2} \text { reduced the expression of innate } \\
\text { immune effectors } \mathrm{L}-6 \text { and TNF- } a\end{array}$ \\
\hline Wang et al. [21] & $\begin{array}{l}\text { Endotoxin stimulation. In vitro } \\
\text { human and mouse macrophages }\end{array}$ & $\begin{array}{l}5,9 \\
12.5 \\
20 \%\end{array}$ & $\begin{array}{l}\text { Hypercapnia reduced cytokine release } \\
(\text { IL-6, TNF-a) }\end{array}$ \\
\hline
\end{tabular}

HCA hypercapnic acidosis, ADAM-17 ADAM metallopeptidase 17, ASK-1 apoptosis signal-regulating kinase-1, EGRF epidermal growth factor receptor, IkB inhibitory kappa B, IL-6 interleukin-6, IR ischemia-reperfusion, JNK c-Jun N-terminal kinase, MDA malondialdehyde, MPO myeloperoxidase, NF-kB nuclear factor kappa B, p44/42 MAPK p44/p42 mitogenactivated protein kinase, TNF- $a$ tumor necrosis factor- $a$, TNFR tumor necrosis factor receptor, VILI ventilator-induced lung injury

\section{Effects of hypercapnia on airway resistance}

Hypercapnia may either decrease or increase airway resistance. Alveolar hypercapnia decreases airway resistance by relaxing smooth muscle small bronchi (a direct effect) in healthy subjects [25], while systemic hypercapnia causes vagal nerve-mediated constriction of the larger airway (an indirect effect) in animal models [26]. These opposing but balanced effects may produce a little net alteration in airway resistance [27].

\section{Effects of hypercapnia on the oxygenating capacity of the lung}

Hypercapnia potentiates hypoxic pulmonary vasoconstriction with a reduction in intrapulmonary shunt, improving gas exchange in normal [28-30] and diseased lungs [31, 32]. Hypercapnia also increases lung compliance, directing ventilation to the underventilated lung regions resulting in a better match between ventilation and perfusion in the lung of dogs [33]. The mechanism might be through increased alveolar surfactant secretion and more effective surface tension-lowering properties of surfactant under acidic conditions [31]. However, in an in vivo rat model of prolonged E. coli pneumonia, hypercapnia lowered static lung compliance compared to normocapnia [17]. Sustained hypercapnia may impair neutrophil function, increasing bacterial load, contributing to increased lung injury and worst compliance [14]. 
Both hypercapnia and hypercapnic acidosis shift the hemoglobin-oxygen dissociation curve to the right and may increase hematocrit, augmenting the release of oxygen to the tissues in a canine model [34]. It also increases cardiac output through sympathoadrenal mechanisms [35]. The secondary rise in cardiac output is associated with increased preload, afterload, contractility, and elevated heart rate [36]. The overall effect is better oxygenation and improved global oxygen supply.

On the other hand, hypercapnia lowers alveolar oxygen tension by the following formula $\mathrm{P}_{\mathrm{A}} \mathrm{O}_{2}=\mathrm{FiO}_{2}\left(P_{B}-47\right)-\left(\mathrm{PaCO}_{2} / R\right)$, where $\mathrm{P}_{\mathrm{A}} \mathrm{O}_{2}$ is the alveolar oxygen tension, $P_{B}$ is the barometric pressure, and $R$ is the respiratory quotient. However, compared to alterations in $\mathrm{FiO}_{2}$ [37], the effect on alveolar oxygenation by alterations in alveolar ventilation is small.

The overall effect of these mechanisms is that blood oxygenation may remain mostly unchanged or improved.

\section{Effects of hypercapnia on diaphragm function}

Hypercapnic acidosis preserves diaphragmatic contractility and prevents ventilation-induced diaphragmatic myosin loss and inflammation in pigs [38]. However, hypercapnic acidosis impairs diaphragmatic function in spontaneously breathing patients, through effects on afferent transmission by the vagal nerve [39].

The clinical effect of hypercapnia upon diaphragmatic function needs to be further elucidated.

\section{Effects of hypercapnia on pulmonary vasculature}

In models of pulmonary hypertension induced by chronic hypoxia and right ventricular dysfunction, hypercapnic acidosis attenuates pulmonary hypertension, normalizes right ventricular function, and preserves the endothelial integrity and pulmonary vascular remodeling [40-42]. The effects of hypercapnic acidosis on vasoconstriction and resistance in the pulmonary circulation have also been found in humans [35]. These effects are exacerbated in the setting of preexisting pulmonary hypertension, such as found with ARDS [43].

\section{The impact of hypercapnia in acute respiratory distress syndrome}

Supportive care with mechanical ventilation remains the mainstay of ARDS management with a goal to minimize lung injury caused by the forces created by mechanical ventilation. Treatment algorithms for ARDS typically begin with optimization of the settings to achieve the so-called lung-protective ventilation and proceed through increasing invasiveness based on physiological goals of gas exchange. These include higher positive end-expiratory pressures, lung recruitment manoeuvers, prone positioning, and extracorporeal removal of carbon dioxide.

\section{Permissive hypercapnia}

Lung-protective ventilation with volumes limited to $6-8 \mathrm{~mL} / \mathrm{kg}$ of predicted body weight (PBW) or lower, and plateau pressure $<30 \mathrm{~cm} \mathrm{H}_{2} \mathrm{O}$, dramatically increases survival [2]. As a consequence of reducing alveolar ventilation with lower tidal volumes, hypercapnia results. Recognizing that low tidal volume ventilation confers survival 
benefits by reducing lung stretch and the cyclical collapse of alveoli, clinicians have accepted hypercapnia, giving rise to the concept of permissive hypercapnia [44]. However, it remains unclear whether hypercapnic acidosis carries survival benefits independent of using low tidal volumes (Table 3).

In a retrospective analysis of the ARDS network, hypercapnic acidosis was associated with lower mortality in the group of patients receiving tidal volumes of $12 \mathrm{~mL} / \mathrm{kg}$ PBW. However, there was no survival benefit in patients ventilated at tidal volumes of $6 \mathrm{~mL} /$ kg PBW [45]. It was hypothesized that lung-protective ventilation reduced lung injury caused by the ventilator to a point where the protective effect of hypercapnic acidosis could not be detected.

In a multicenter randomized clinical trial comparing low $(7 \mathrm{~mL} / \mathrm{kg} \mathrm{PBW})$ with conventional tidal volumes $(10 \mathrm{~mL} / \mathrm{kg} \mathrm{PBW})$, a trend towards higher mortality was observed in patients who developed hypercapnia and acidosis [46]. These findings resulted in a premature stop of that trial, making interpretation of the results difficult.

Recently, a post hoc analysis of three prospective non-interventional international studies in ARDS patients was published [47]. In this analysis, severe hypercapnia $\left(\mathrm{PaCO}_{2}>50 \mathrm{mmHg}\right)$ was associated with higher mortality and more organ failures compared to patients with normocapnia. Acidosis or the combination of hypercapnia and acidosis independently increased the risk of mortality in the intensive care unit. The incidence of severe hypercapnia increased significantly with the time $(1998,2004$, and 2010) as a consequence of the diverse respiratory strategies practiced over the years, which may reflect the feeling of many intensivists that hypercapnia could be beneficial [47].

Finally, one retrospective analysis including over 250,000 ARDS patients receiving mechanical ventilation showed that patients who developed hypercapnic acidosis $\left(\mathrm{pH}<7.35 \mathrm{PaCO}_{2}>65 \mathrm{mmHg}\right)$ during the first $24 \mathrm{~h}$ of mechanical ventilation had significantly higher mortality than those who had compensated hypercapnia or normocapnia [48].

\section{Lung overdistension}

The rationale for using positive end-expiratory pressure (PEEP) is to mitigate the injurious effects of repetitive opening and closing of lung units by restoring the functional size of the lung, promoting lung protection, and improving gas exchange and lung mechanics. However, high levels of PEEP may lead to overdistension of lung units, especially those that remained normally aerated within heterogeneous ARDS lungs, and

Table 3 Randomized controlled studies in lung-protective ventilation and $\mathrm{PaCO}_{2}$ levels

\begin{tabular}{lllll}
\hline Study & Mortality benefit & $\begin{array}{l}\mathrm{PaCO}_{2} \text { in control arm } \\
(\mathrm{mmHg} \pm \mathrm{SD})\end{array}$ & $\begin{array}{l}\mathrm{PaCO}_{2} \text { in LPV arm } \\
(\mathrm{mmHg} \pm \mathrm{SD})\end{array}$ & Buffer used \\
\hline ARDSNet [2] & Yes & $35.8 \pm 8.0$ & $40.0 \pm 10.0$ & Yes \\
Amato et al. [66] & Yes & $36.0 \pm 1.5$ & $58.0 \pm 3.0$ & No \\
Brochard et al. [46] & No & $41.0 \pm 7.5$ & $59.5 \pm 19.0$ & No \\
Brower et al. [67] & No & $40.1 \pm 1.6$ & $50.3 \pm 3.5$ & Yes \\
Stewart et al. [68] & No & $46.1 \pm 10$ & $54.5 \pm 15$ & No \\
\hline
\end{tabular}

LPV lung-protective ventilation 
this may increase alveolar dead space [49-51]. The consequence of this will be a rise of carbon dioxide levels.

In a recent international randomized clinical trial in ARDS patients, the use of the "open lung approach" actually increased 28-day mortality [52]. Notably, this trial used aggressive recruitment manoeuvers and "super high" levels of positive end-expiratory pressure compared to previous trials [53-55]. It is also worth to note that patients in this trial had much higher blood carbon dioxide levels than patients in previous trials that tested the "open lung approach." It could be hypothesized that this reflects an increase in dead space secondary to overdistension.

\section{Extracorporeal $\mathrm{CO}_{2}$ removal (Table 4 and Additional file 1)}

Despite lung-protective ventilation strategies, up to $30 \%$ of patients with ARDS have evidence of tidal hyperinflation, representing a potential risk of VILI [56]. A strategy of "ultraprotective ventilation" with tidal volumes lower than $6 \mathrm{~mL} / \mathrm{kg}$ PBW requires extracorporeal decapneization.

This approach has been tested in two trials in ARDS patients, resulting in less lung injury caused by ventilation [57] and a decrease in the number of ventilation days [58]. In one feasibility study, $\mathrm{ECCO}_{2} \mathrm{R}$ facilitated ventilation with ultralow tidal volumes near to $3 \mathrm{~mL} / \mathrm{kg} \mathrm{PBW}$, while preventing hypercapnic acidosis [59]. These findings were confirmed in a recently completed international multicenter randomized clinical trial (ClinicalTrials.gov/ct2/show/NCT02282657). One currently recruiting randomized clinical trial evaluates whether ultraprotective ventilation by employing $\mathrm{ECCO}_{2} \mathrm{R}$ affects 90-day mortality in patients with hypoxemic acute respiratory failure (ClinicalTrials.gov/ct2/show/NCT02654327).

Although $\mathrm{ECCO}_{2} \mathrm{R}$ seems to be effective in mitigating hypercapnic acidosis and possibly in reducing VILI and mechanical ventilation days, $\mathrm{ECCO}_{2} \mathrm{R}$ may have pulmonary and hemodynamic consequences. It can be associated to adverse effects such worsening hypoxemia and increased $\mathrm{FiO}_{2}$ requirements due to a decrease in mean airway pressure, low ventilation-perfusion ratio, and lower partial pressure of alveolar oxygen secondary to a decreased lung respiratory quotient $[60,61]$. Besides, because of the low flow system of $\mathrm{ECCO}_{2} \mathrm{R}$, higher anticoagulation requirements are needed in order to maintain $\mathrm{ECCO}_{2} \mathrm{R}$ efficiency and performance. Therefore, significant complications may occur as a consequence of anticoagulation or catheter insertion with hemodynamic instability and a higher number of red blood cell transfusions needed $[59,62-64]$.

It is worth to say that $\mathrm{ECCO}_{2} \mathrm{R}$ may be a promising adjuvant therapeutic strategy for reducing the impact of mechanical ventilation through ultraprotective ventilation rather than to mitigate hypercapnia in patients under conventional lung-protective ventilation. For the time being, the available literature does not provide definitive information on the usefulness of $\mathrm{ECCO}_{2} \mathrm{R}$ in patients with acute respiratory failure. Its use for the moment is experimental.

\section{Conclusion}

It is increasingly recognized that $\mathrm{CO}_{2}$ is much more than just a waste product of cellular metabolism. Indeed, it should be seen as a potent biological agent that exerts protective as well as harmful effects. Hypercapnia may develop in ARDS patients, and 
Table 4 Relevant clinical studies of $\mathrm{ECCO}_{2} \mathrm{R}$ in ARDS patients

\begin{tabular}{ll}
\hline Study & $\mathrm{ECCO}_{2} \mathrm{R}$ technique \\
\hline Terragni et al. [56] & $\begin{array}{l}\text { Modified continuous W hemofiltration } \\
\text { system with membrane lung via a 14-Fr sin- } \\
\text { gle dual lumen catheter (femoral) with an } \\
\text { extracorporeal blood flow of 191-422 } \mathrm{mL} / \\
\text { min }\end{array}$ \\
& \\
Bein et al. [58] & \\
& Femoral AV pumpless extracorporeal lung \\
& assist (PECLA) via a 15-Fr arterial cannula and \\
& 17-Fr venous cannula with a mean extracor- \\
& poreal blood flow of $1.3 \mathrm{~L} /$ min
\end{tabular}

Description and results

Prospective study.

Ten ARDS patients with $28 \leq$ Pplat $\leq 30$ after $72 \mathrm{~h}$ of ARDSNet ventilation were placed on $\mathrm{ECCO}_{2} \mathrm{R}$ and had a progressive reduction in $\mathrm{V}_{\mathrm{T}}$.

$V_{T}$ was reduced from $6.3 \pm 0.2$ to $4.2 \pm 0.3$

$\mathrm{mL} / \mathrm{kg}$ PBW and Pplat decreased from 29.1

\pm 1.2 to $25.0 \pm 1.2 \mathrm{cmH}_{2} \mathrm{O}(P<0.001)$.

Consequent respiratory acidosis was managed by $\mathrm{ECCO}_{2} \mathrm{R}$.

Improvement of morphological markers of lung protection and reduction in pulmonary cytokines $(P<0.01)$ after $72 \mathrm{~h}$ of ventilation with $V T<6 \mathrm{~mL} / \mathrm{kg}$ PBW.

No patient-related complications. Membrane clotting in three patients.

Randomized controlled trial.

Moderate/severe ARDS after 24-h

stabilization period with higher PEEP.

Randomized to $\mathrm{ECCO}_{2} \mathrm{R}$ group with $\sim 3 \mathrm{~mL} /$ $\mathrm{kg}$ PBW ventilation or control group with $6 \mathrm{~mL} / \mathrm{kg}$ PBW ventilation.

There were no significant differences in VFDs at day 28 ( 10 vs. 9 days, $P=0.78$ ) or day 60 (33 vs. 29, $P=0.47$ ).

Post hoc analysis showed that patients with $\mathrm{P} / \mathrm{F} \leq 150$ at randomization in $\mathrm{ECCO}_{2} \mathrm{R}$ group had a significantly shorter duration of ventilation (VFDs at day 60,41 vs. $28, P=$ 0.033).

Significantly higher red blood cell transfusion in the PECLA group up to day 10 (3.7 vs. 1.5 units, $P<0.05$ ).

Fanelli et al. [59] W configuration via a 15.5-Fr single dual lumen catheter (femoral or jugular) with a mean extracorporeal blood flow of $435 \mathrm{~mL} /$ $\min$
Prospective study.

Moderate/severe ARDS

$V_{T}$ was reduced from baseline to $4 \mathrm{~mL} / \mathrm{kg}$ PBW.

Low-flow $\mathrm{ECCO}_{2} \mathrm{R}$ was initiated when $\mathrm{pH}<$ 7.25 and $\mathrm{PaCO}_{2}>60 \mathrm{mmHg}$.

$\mathrm{ECCO}_{2} \mathrm{R}$ was effective in correcting $\mathrm{pH}$ and $\mathrm{PaCO}_{2}$.

Life-threatening hypoxemia such as prone position and ECMO were necessary in four and two patients, respectively.

Schmidt et al. [69] $W$ configuration managed with renal replacement platform via a $15.5-\mathrm{Fr}$ single dual lumen catheter (femoral or jugular) with a mean extracorporeal blood flow of 421 $\mathrm{mL} / \mathrm{min}$

Prospective multicenter study. Twenty-two patients with mild/moderate ARDS

$V_{T}$ gradually reduced following 2-h run-in time from 6 to $5,4.5$, and $4 \mathrm{~mL} / \mathrm{kg}$ every 30 min and PEEP adjusted to reach $23 \leq \mathrm{P}_{\text {plat }} \leq$ $25 \mathrm{cmH}_{2} \mathrm{O}$.

No patients required ECMO.

No worsening oxygenation.

Low-flow $\mathrm{ECCO}_{2} \mathrm{R}$ managed by RRT platform easily and safely enabled ultraprotective ventilation.

Performance of RRT ECCO 2 in severe ARDS patients not known.

Prospective multicenter study. Ninety-five patients with moderate ARDS. $V_{T}$ progressively decreased to $4 \mathrm{~mL} / \mathrm{kg}$ PBW.

PEEP adjusted to reach $23 \leq$ Pplat $\leq$ $25 \mathrm{cmH}_{2} \mathrm{O}$.

Objective to maintain $\mathrm{PaCO}_{2} \pm 20 \%$ of baseline values obtained at $\mathrm{V}_{T} 6 \mathrm{~mL} / \mathrm{kg} \mathrm{IBW}$ with $\mathrm{pH}>7.30$. 
Table 4 Relevant clinical studies of $\mathrm{ECCO}_{2} \mathrm{R}$ in ARDS patients (Continued)

\begin{tabular}{|c|c|c|}
\hline Study & $\mathrm{ECCO}_{2} \mathrm{R}$ technique & Description and results \\
\hline & & $\begin{array}{l}\mathrm{ECCO}_{2} \mathrm{R} \text { was able to reduce Pplat from } 26 \pm \\
5 \mathrm{CmH}_{2} \mathrm{O} \text { to } 23 \pm 3 \mathrm{cmH}_{2} \mathrm{O}(P<0.01) \text { in } 73 \% \\
\text { of patients. } \\
\mathrm{ECCO}_{2} \mathrm{R} \text { was able to increase PEEP from } 12 \\
\pm 4 \mathrm{cmH}_{2} \mathrm{O} \text { to } 14 \pm 4 \mathrm{cmH}_{2} \mathrm{O}(P<0.01) \text {. } \\
\mathrm{ECCO} \mathrm{CO}_{2} \mathrm{R} \text { allowed } \triangle \mathrm{P} \text { reduction from } 13 \pm 5 \text { to } \\
9 \pm 4 \mathrm{cmH}_{2} \mathrm{O}(P<0.01) \text {. } \\
\text { There were no significant changes in pH, } \\
\mathrm{PaCO} \text {, and } \mathrm{PaO}_{2} / \mathrm{FiO}_{2} \text { with } \mathrm{V}_{\mathrm{T}} \text { reduction to } \\
4 \mathrm{~mL} / \mathrm{kg} / \mathrm{BW} \\
\mathrm{ECCO} 2 \mathrm{R} \text { device length: } 5(3-8 \text { days). } \\
\text { Derecruitment/hypoxia }(n=2) \text { that need to } \\
\text { increase } \mathrm{V}_{\mathrm{T}} \text {, hemolysis }(n=3) \text {. Hemorrhage } \\
\text { at the cannula insertion point }(n=4) \text {, } \\
\text { pneumothorax }(n=1) \text {. }\end{array}$ \\
\hline
\end{tabular}

what the exact impact of high carbon dioxide levels on the outcome remains uncertain. More importantly, whether it should be accepted or whether it should be prevented or treated with invasive techniques for extracorporeal removal remains highly uncertain.

\section{Additional file}

Additional file 1: Table S1. Ongoing studies of $\mathrm{ECCO}_{2} \mathrm{R}$ in ARDS. (DOCX $16 \mathrm{~kb}$ )

\section{Abbreviations}

ARDS: Acute respiratory distress syndrome; $\mathrm{CO}_{2}$ : Carbon dioxide; $\mathrm{ECCO}_{2} \mathrm{R}$ : Extracorporeal carbon dioxide removal; HCA: Hypercapnic acidosis; LPS: Lipopolysaccharide; NF-kB: Nuclear factor kappa B; PaCO, Partial arterial pressure of carbon dioxide; $\mathrm{PaO}_{2}$ : Partial alveolar pressure of oxygen; PBW: Predicted body weight; VILI: Ventilator-induced lung injury

\section{Acknowledgements}

Not applicable.

\section{Funding}

This article did not receive sponsorship for publication

Availability of data and materials

Data sharing not applicable to this article as no datasets were generated or analyzed during the current study.

\section{About this supplement}

This article has been published as part of the supplement Intensive Care Medicine Experimental Volume 7 Supplement 1 2019: Proceedings from the Third International Symposium on Acute Pulmonary Injury and Translational Research (INSPIRES III). The full contents of the supplement are available at https://icm-experimental.springeropen.com/articles/ supplements/volume-7-supplement-1.

Authors' contributions

All the authors have contributed equally to the elaboration of this article. All authors read and approved the final manuscript.

\section{Ethics approval and consent to participate}

Not applicable.

\section{Consent for publication}

Not applicable.

Competing interests

The authors declare that they have no competing interests.

\section{Publisher's Note}

Springer Nature remains neutral with regard to jurisdictional claims in published maps and institutional affiliations. 


\section{Author details}

${ }^{1}$ Intensive Care Unit, Hospital Universitario Sagrado Corazón, Carrer de Viladomat, 288, 08029 Barcelona, Spain. ${ }^{2}$ Department of Medicine, Universitat Autònoma de Barcelona, Bellatera, Spain. ${ }^{3}$ Critical Care Center, Corporació Sanitària I Universitària Parc Taulí, Sabadell, Spain. ${ }^{4}$ Institut d'Investigació i Innovació Parc Taulí (I3PT), Sabadell, Spain. ${ }^{5}$ Department of Intensive Care, Amsterdam University Medical Centers, University of Amsterdam, Amsterdam, The Netherlands. ${ }^{6}$ Respiratory Medicine, Amsterdam University Medical Centers, University of Amsterdam, Amsterdam, The Netherlands. 'Laboratory of Experimental Intensive Care and Anesthesiology (L.E.I.C.A), Amsterdam University Medical Centers, University of Amsterdam, Amsterdam, The Netherlands. ${ }^{8}$ Mahidol Oxford Tropical Medicine Research Unit (MORU), Mahidol University, Bangkok, Thailand. ${ }^{9}$ Centro de Investigación en Red de Enfermedades Respiratorias (CIBERES), Madrid, Spain.

Received: 21 February 2019 Accepted: 7 March 2019

Published: 25 July 2019

\section{References}

1. Nuckton TJ, Alonso JA, Kallet RH et al (2002) Pulmonary dead-space fraction as a risk factor for death in the acute respiratory distress syndrome. N Engl J Med 346:1281-1286

2. The Acute Respiratory Distress Syndrome Network (2000) Ventilation with lower tidal volumes as compared with traditional tidal volumes for acute lung injury and the acute respiratory distress syndrome. N Engl J Med 342:1301-1308

3. Putensen C, Theuerkauf N, Zinserling J et al (2009) Meta-analysis: ventilation strategies and outcomes of the acute respiratory distress syndrome and acute lung injury. Ann Intern Med 151(8):566-576

4. Broccard AF, Hotchkiss JR, Vannay C et al (2001) Protective effects of hypercapnic acidosis on ventilator-induced lung injury. Am J Respir Crit Care Med 164:802-806

5. Peltekova V, Engelberts D, Otulakowski G et al (2010) Hypercapnic acidosis in ventilator-induced lung injury. Intensive Care Med 36:869-878

6. Laffey JG, Tanaka M, Engelberts D et al (2000) Therapeutic hypercapnia reduces pulmonary and systemic injury following in vivo lung reperfusion. Am J Respir Crit Care Med 162:2287-2294

7. Shibata K, Cregg N, Engelberts D et al (1998) Hypercapnic acidosis may attenuate acute lung injury by inhibition of endogenous xanthine oxidase. Am J Respir Crit Care Med 158(5 Pt):1578-1584

8. O'Toole D, Hassett P, Contreras M et al (2009) Hypercapnic acidosis attenuates pulmonary epithelial wound repair by an NF-kappaB dependent mechanism. Thorax. 64:976-982

9. Briva A, Vadász I, Lecuona E et al (2007) High $\mathrm{CO}_{2}$ levels impair alveolar epithelial function independently of pH. PLoS One 2:e1238

10. Welch LC, Lecuona E, Briva A et al (2010) Extracellular signal-regulated kinase (ERK) participates in the hypercapniainduced Na,K-ATPase downregulation. FEBS Lett 584:3985-3989

11. Lecuona $\mathrm{E}$, Sun $\mathrm{H}$, Chen J et al (2013) Protein kinase A-lalpha regulates Na,K-ATPase endocytosis in alveolar epithelial cells exposed to high $\mathrm{CO}_{2}$ concentrations. Am J Respir Cell Mol Biol 48:626-634

12. Contreras M, Ansari B, Curley G et al (2012) Hypercapnic acidosis attenuates ventilation-induced lung injury by a nuclear factor-kappaB-dependent mechanism. Crit Care Med 40:2622-2630

13. Cummins EP, Oliver KM, Lenihan $\mathrm{CR}$ et al (2010) NF-KB links $\mathrm{CO}_{2}$ sensing to innate immunity and inflammation in mammalian cells. J Immunol 185:4439-4445

14. Laffey JG, Engelberts D, Kavanagh BP (2000) Buffering hypercapnic acidosis worsens acute lung injury. Am J Respir Crit Care Med 161:141-146

15. Otulakowski G, Engelberts D, Gusarova GA et al (2014) Hypercapnia attenuates ventilator induced lung injury via a disintegrin and metalloprotease-17. J Physiol 592:4507-4521

16. Takeshita K, Suzuki Y, Nishio K et al (2003) Hypercapnic acidosis attenuates endotoxin-induced nuclear factor-[kappa]B activation. Am J Respir Cell Mol Biol 29(1):124-132

17. O'Croinin DF, Nichol AD, Hopkins N et al (2008) Sustained hypercapnic acidosis during pulmonary infection increases bacterial load and worsens lung injury. Crit Care Med 36(7):2128-2135

18. Lang JD Jr, Chumley P, Eiserich JP et al (2000) Hypercapnia induces injury to alveolar epithelial cells via a nitric oxidedependent pathway. Am J Phys Lung Cell Mol Phys 279:L994-L1002

19. Vohwinkel CU, Lecuona $\mathrm{E}$, Sun $\mathrm{H}$ et al (2011) Elevated CO(2) levels cause mitochondrial dysfunction and impair cell proliferation. J Biol Chem 286(43):37067-37076

20. Yang WC, Song CY, Wang N et al (2013) Hypercapnic acidosis confers antioxidant and anti-apoptosis effects against ventilator-induced lung injury. Lab Investig 93:1339-1349

21. Wang N, Gates KL, Trejo $\mathrm{H}$ et al (2010) Elevated $\mathrm{CO}_{2}$ selectively inhibits interleukin-6 and tumor necrosis factor expression and decreases phagocytosis in the macrophage. FASEB J 24:2178-2190

22. Oliver KM, Lenihan CR, Bruning U et al (2012) Hypercapnia induces cleavage and nuclear localization of RelB protein giving insight into $\mathrm{CO}_{2}$ sensing and signaling. J Biol Chem 287:14004-14011

23. Laffey JG, Engelberts D, Duggan M et al (2003) Carbon dioxide attenuates pulmonary impairment resulting from hyperventilation. Crit Care Med 31:2634-2640

24. Lecuona E, Trejo HE, Sznajder JI (2007) Regulation of Na,K-ATPase during acute lung injury. J Bioenerg Biomembr 39(56):391-395

25. D'Angelo E, Calderini IS, Tavola M (2001) The effects of $\mathrm{CO}_{2}$ on respiratory mechanics in anesthetized paralyzed humans. Anesthesiology. 94(4):604-610

26. Lele EE, Hantos Z, Bitay M et al (2011) Bronchoconstriction during alveolar hypocapnia and systemic hypercapnia in dogs with a cardiopulmonary bypass. Respir Physiol Neurobiol 175(1):140-145

27. Butler J, Caro CG, Alcala R et al (1960) Physiological factors affecting airway resistance in normal subjects and in patients with obstructive respiratory disease. J Clin Invest 39:584-591

28. Swenson ER, Robertson HT, Hlastala MP (1994) Effects of inspired carbon dioxide on ventilation-perfusion matching in normoxia, hypoxia, and hyperoxia. Am J Respir Crit Care Med 149:1563-1569 
29. Brogan TV, Hedges RG, McKinney S et al (2000) Pulmonary NO synthase inhibition and inspired $\mathrm{CO}_{2}$ : effects on $\mathrm{V}^{\prime} / \mathrm{Q}^{\prime}$ and pulmonary blood flow distribution. Eur Respir J 16:288

30. Brogan TV, Robertson HT, Lamm WJ et al (2004) Carbon dioxide added late in inspiration reduces ventilation-perfusion heterogeneity without causing respiratory acidosis. J Appl Physiol 96:1894-1898

31. Keenan RJ, Todd TR, Demajo W et al (1990) Effects of hypercarbia on arterial and alveolar oxygen tensions in a model of gram-negative pneumonia. Appl Phys 68:1820-1825

32. Sinclair SE, Kregenow DA, Starr I et al (2006) Therapeutic hypercapnia and ventilation-perfusion matching in acute lung injury: low minute ventilation vs inspired $\mathrm{CO}_{2}$. Chest. 130:85-92

33. Wildeboer-Venema $F(1980)$ The influences of temperature and humidity upon the isolated surfactant film of the dog. Respir Physiol 39:63-71

34. Torbati D, Mangino MJ, Garcia E et al (1998) Acute hypercapnia increases the oxygen-carrying capacity of the blood in ventilated dogs. Crit Care Med 26(11):1863-1867

35. Kregenow DA, Swenson ER (2002) The lung and carbon dioxide: implications for permissive and therapeutic hypercapnia. Eur Respir J 20:6-11

36. Cullen DJ, Eger El 2nd (1974) Cardiovascular effects of carbon dioxide in man. Anesthesiology. 41(4):345-349

37. Bidani A, Tzouanakis AE, Cardenas VJ et al (1994) Permissive hypercapnia in acute respiratory failure. JAMA. 272(12):957-962

38. Jung B, Sebbane M, Le Goff C et al (2013) Moderate and prolonged hypercapnic acidosis may protect against ventilator-induced diaphragmatic dysfunction in healthy piglet: an in vivo study. Crit Care 17:R15

39. Jonville S, Delpech N, Dejean A (2002) Contribution of respiratory acidosis to diaphragmatic fatigue at exercise. Eur Respir J 19:1079-1086

40. Dunlop K, Gosal K, Kantores C et al (2014) Therapeutic hypercapnia prevents inhaled nitric oxide-induced rightventricular systolic dysfunction in juvenile rats. Free Radic Biol Med 69:35-49

41. Peng G, Ivanovska J, Kantores $C$ et al (2012) Sustained therapeutic hypercapnia attenuates pulmonary arterial Rho-kinase activity and ameliorates chronic hypoxic pulmonary hypertension in juvenile rats. Am J Physiol Heart Circ Physiol 302:H2599-H2611

42. Ketabchi F, Ghofrani HA, Schermuly RT et al (2012) Effects of hypercapnia and NO synthase inhibition in sustained hypoxic pulmonary vasoconstriction. Respir Res 13:7

43. Lhéritier G, Legras A, Caille A et al (2013) Prevalence and prognostic value of acute cor pulmonale and patent foramen ovale in ventilated patients with early acute respiratory distress syndrome: a multicenter study. Intensive Care Med 39:1734-1742

44. Curley GF, Laffey JG, Kavanagh BP (2013) CrossTalk proposal: there is added benefit to providing permissive hypercapnia in the treatment of ARDS. J Physiol 591(11):2763-2765

45. Kregenow DA, Rubenfeld GD, Hudson LD et al (2006) Hypercapnic acidosis and mortality in acute lung injury. Crit Care Med 34:1-7

46. Brochard L, Roudot-Thoraval F, Roupie E et al (1998) Tidal volume reduction for prevention of ventilator-induced lung injury in acute respiratory distress syndrome. Am J Respir Crit Care Med 158:1831-1838

47. Nin N, Muriel A, Peñuelas O et al (2017) Severe hypercapnia and outcome of mechanically ventilated patients with moderate or severe acute respiratory distress syndrome. Intensive Care Med 43:200-208

48. Tiruvoipati R, Pilcher D, Buscher $\mathrm{H}$ et al (2017) Effects of hypercapnia and hypercapnic acidosis on hospital mortality in mechanically ventilated patients. Crit Care Med 45:e649-e656

49. Suter PM, Fairley B, Isenberg MD (1975) Optimum end-expiratory airway pressure in patients with acute pulmonary failure. N Engl J Med 292(6):284-289

50. Blanch L, Lucangelo U, Lopez-Aguilar J et al (1999) Volumetric capnography in patients with acute lung injury: effects of positive end-expiratory pressure. Eur Respir J 13(5):1048-1054

51. Beydon L, Uttman L, Rawal R et al (2002) Effects of positive end-expiratory pressure on dead space and its partitions in acute lung injury. Intensive Care Med 28(9):1239-1245

52. Cavalcanti AB, Suzumura ÉA, Laranjeira LN et al (2017) Effect of lung recruitment and titrated positive end-expiratory pressure (PEEP) vs low PEEP on mortality in patients with acute respiratory distress syndrome: a randomized clinical trial. JAMA. 318(14):1335-1345

53. Brower RG, Lanken PN, Maclntyre N et al (2004) Higher versus lower positive end-expiratory pressures in patients with the acute respiratory distress syndrome. N Engl J Med 351(4):327-336

54. Mercat A, Richard JC, Vielle B et al (2008) Positive end-expiratory pressure setting in adults with acute lung injury and acute respiratory distress syndrome: a randomized controlled trial. JAMA. 299(6):646-655

55. Meade MO, Cook DJ, Guyatt GH et al (2009) Ventilation strategy using low tidal volumes, recruitment maneuvers, and high positive end-expiratory pressure for acute lung injury and acute respiratory distress syndrome: a randomized controlled trial. JAMA. 299(6): $637-645$

56. Terragni PP, Rosboch G, Tealdi A et al (2007) Tidal hyperinflation during low tidal volume ventilation in acute respiratory distress syndrome. Am J Respir Crit Care Med 175(2):160-166

57. Terragni PP, Del Sorbo L, Mascia L et al (2009) Tidal volume lower than $6 \mathrm{ml} / \mathrm{kg}$ enhances lung protection: role of extracorporeal carbon dioxide removal. Anesthesiology. 111(4):826-835. https://doi.org/10.1097/ALN.0b013e3181b764d2

58. Bein T, Weber-Carstens $\mathrm{S}$, Goldmann A et al (2013) Lower tidal volume strategy $(\approx 3 \mathrm{ml} / \mathrm{kg})$ combined with extracorporeal $\mathrm{CO}_{2}$ removal versus "conventional" protective ventilation $(6 \mathrm{ml} / \mathrm{kg})$ in severe ARDS: the prospective randomized Xtravent-study. Intensive Care Med 39:847-856

59. Fanelli V, Ranieri MV, Mancebo J et al (2016) Feasibility and safety of low-flow extracorporeal carbon dioxide removal to facilitate ultra-protective ventilation in patients with moderate acute respiratory distress syndrome. Crit Care 20(1):36 https://doi.org/10.1186/s13054-016-1211-y

60. Gattinoni L (2016) Ultra-protective ventilation and hypoxemia. Crit Care 20:130-131

61. Gattinoni L, Kolobow T, Tomlinson T et al (1978) Low-frequency positive pressure ventilation with extracorporeal carbon dioxide removal (LFPPV-ECCO 2 R): an experimental study. Anesth Analg 57(4):470-477

62. Kluge S, Braune SA, Engel M et al (2012) Avoiding invasive mechanical ventilation by extracorporeal carbon dioxide removal in patients failing noninvasive ventilation. Intensive Care Med 38:1632-1639

63. Burki NK, Mani RK, Herth FJF et al (2013) COPD a novel extracorporeal $\mathrm{CO}_{2}$ removal results of a pilot study of hypercapnic respiratory failure in patients with COPD. Chest. 143(3):678-686. https://doi.org/10.1378/chest.12-0228 
64. Del Sorbo L, Fan E, Nava S et al (2016) $\mathrm{ECCO}_{2} \mathrm{R}$ in COPD exacerbation only for the right patients and with the right strategy. Intensive Care Med 42(11):1830-1831

65. Doerr CH, Gajic O, Berrios JC et al (2005) Hypercapnic acidosis impairs plasma membrane wound resealing in ventilator-injured lungs. Am J Respir Crit Care Med 171:1371-1377

66. Amato MB, Barbas CS, Medeiros DM et al (1998) Effect of a protective-ventilation strategy on mortality in the acute respiratory distress syndrome. N Engl J Med 338:347-354

67. Brower RG, Shanholtz CB, Fessler HE et al (1999) Prospective, randomized, controlled clinical trial comparing traditional versus reduced tidal volume ventilation in acute respiratory distress syndrome patients. Crit Care Med 27:1492-1498

68. Stewart TE, Meade MO, Cook DJ et al (1998) Evaluation of a ventilation strategy to prevent barotrauma in patients at high risk for acute respiratory distress syndrome. Pressure- and Volume-Limited Ventilatory Strategy Group. N Engl J Med 338:355-361

69. Schmidt M, Jaber S, Zogheib E et al (2018) Feasibility and safety of low-flow extracorporeal $\mathrm{CO}_{2}$ removal managed with a renal replacement platform to enhance lung-protective ventilation of patients with mild-to-moderate ARDS. Crit Care 22(1):122

70. Combes A, Fanelli V, Pham T et al (2019) Feasibility and safety of extracorporeal removal to enhance protective ventilation in acute respiratory distress syndrome: the SUPERNOVA study. Intensive Care Med. (Epub ahead of print).

Submit your manuscript to a SpringerOpen ${ }^{\circ}$ journal and benefit from:

- Convenient online submission

Rigorous peer review

- Open access: articles freely available online

High visibility within the field

- Retaining the copyright to your article

Submit your next manuscript at $\boldsymbol{\nabla}$ springeropen.com 